\title{
Phytohabitans suffuscus gen. nov., sp. nov., an actinomycete of the family Micromonosporaceae isolated from plant roots
}

Correspondence

Yōko Takahashi

ytakaha@lisci.kitasato-u.ac.jp

\author{
Yuki Inahashi, ${ }^{1}$ Atsuko Matsumoto, ${ }^{2}$ Hirofumi Danbara, ${ }^{3}$ Satoshi Ōmura ${ }^{2}$ \\ and Yōko Takahashi ${ }^{1,2}$ \\ ${ }^{1}$ Graduate School of Infection Control Sciences, Kitasato University, 5-9-1 Shirokane, Minato-ku, \\ Tokyo 108-8641, Japan \\ ${ }^{2}$ Kitasato Institute for Life Sciences, Kitasato University, 5-9-1 Shirokane, Minato-ku, Tokyo 108- \\ 8641, Japan \\ ${ }^{3}$ School of Pharmaceutical Sciences, Kitasato University, 5-9-1 Shirokane, Minato-ku, Tokyo 108- \\ 8641, Japan
}

\begin{abstract}
An actinomycete strain, $\mathrm{K} 07-0523^{\top}$, was isolated from the roots of an orchid collected in Okinawa prefecture, Japan. 16S rRNA gene sequence analysis indicated that the new strain belonged to the family Micromonosporaceae and the similarity values between strain $\mathrm{K} 07-0523^{\top}$ and the type species of 24 genera in the family Micromonosporaceae were 93.3-97.7\%. Strain K07-0523 ${ }^{\top}$ contained D-glutamic acid, glycine, D-alanine, meso-diaminopimelic acid, hydroxydiaminopimelic acid and L-lysine in the cell wall. The major menaquinones were MK-9 $\left(\mathrm{H}_{6}\right), \mathrm{MK}-10\left(\mathrm{H}_{4}\right)$ and MK$10\left(\mathrm{H}_{6}\right)$. Galactose, glucose, mannose, ribose and xylose were present in the whole-cell sugars. The acyl type of the peptidoglycan was glycolyl. Major fatty acids were anteiso- $\mathrm{C}_{17: 0,}$ iso- $\mathrm{C}_{17: 0 \text {, }}$ iso- $\mathrm{C}_{16: 0}$ and iso- $\mathrm{C}_{15: 0}$. Phosphatidylethanolamine was detected as the major phospholipid and corresponded to phospholipid type II. The $\mathrm{G}+\mathrm{C}$ content of the genomic DNA was 73 mol\%. On the basis of phylogenetic and chemotaxonomic data, the new strain represents a member of a new genus and novel species, namely Phytohabitans suffuscus gen. nov., sp. nov., in the family Micromonosporaceae. The type strain of the type species is $\mathrm{K}_{07}-0523^{\top}\left(=\mathrm{DSM} 45306^{\top}=\mathrm{NBRC}\right.$ $\left.105367^{\top}\right)$.
\end{abstract}

It is well known that the majority of actinomycete strains isolated from soil samples belong to the genus Streptomyces (Lechevalier \& Lechevalier, 1967). Okazaki et al. (1995) and Matsumoto et al. (1998) reported that the microbial flora in plant matter was different from that in soil samples and that the majority of species in such samples were rare actinomycetes. We tried to isolate actinomycete strains from plants in order to discover new microbial resources for screening for potential novel natural products. As part of these studies, we have discovered many rare or novel actinomycete strains. One of these strains, K07-0523 ${ }^{\mathrm{T}}$, was identified as being a member of the family Micromonosporaceae. The family Micromonosporaceae was first described by Krasil'nikov (1938), emended by Koch et al. (1996) on the basis of chemotaxonomic data and further emended by Stackebrandt et al. (1997) and Zhi

Abbreviation: SEM, scanning electron microscope.

The GenBank/EMBL/DDBJ accession number for the 16S rRNA gene sequence of strain K07-0523 ${ }^{\top}$ is $A B 490769$.

Additional phylogenetic trees based on maximum-likelihood and maximum-parsimony analyses of $16 \mathrm{~S}$ rRNA gene sequences are available with the online version of this paper. et al. (2009) on the basis of 16S rRNA gene sequence analysis. At the time of writing, the family Micromonosporaceae comprised 24 genera: Micromonospora (Ørskov, 1923), Actinoplanes (Couch, 1950), Pilimelia (Kane, 1966), Dactylosporangium (Thiemann et al., 1967), Catellatospora (Asano \& Kawamoto, 1986), Catenuloplanes (Yokota et al., 1993), Couchioplanes (Tamura et al., 1994), Spirilliplanes (Tamura et al., 1997), Verrucosispora (Rheims et al., 1998), Virgisporangium (Tamura et al., 2001), Asanoa (Lee \& Hah, 2002), Longispora (Matsumoto et al., 2003), Salinispora (Maldonado et al., 2005), Actinocatenispora (Thawai et al., 2006), Polymorphospora (Tamura et al., 2006), Luedemannella (Ara \& Kudo, 2007a), Krasilnikovia (Ara \& Kudo, 2007b), Planosporangium (Wiese et al., 2008), Pseudosporangium (Ara et al., 2008a), Catelliglobosispora (Ara et al., 2008b), Hamadaea (Ara et al., 2008b), Plantactinospora (Qin et al., 2009), Rugosimonospora (Monciardini et al., 2009) and Actinaurispora (Thawai et al., 2010). The characterization and classification of strain $\mathrm{K} 07-0523^{\mathrm{T}}$ is described in this paper.

Strain $\mathrm{K} 07-0523^{\mathrm{T}}$ was isolated from the roots of a variety of orchid collected in Okinawa prefecture, Japan, in March 
2007. The roots were soaked in $70 \%$ ethanol for $30 \mathrm{~s}$ and then soaked in $1 \%$ sodium hypochlorite for $30 \mathrm{~s}$. The roots were then rinsed in sterilized water. A $0.5 \mathrm{~g}$ root sample was dried in a chamber with silica gel and then ground with a mortar and pestle in $5.0 \mathrm{ml}$ extraction solution [0.38\% $\mathrm{K}_{2} \mathrm{HPO}_{4}, 0.12 \% \mathrm{KH}_{2} \mathrm{PO}_{4}, 0.51 \% \mathrm{MgSO}_{4} .7 \mathrm{H}_{2} \mathrm{O}, 0.25 \%$ $\mathrm{NaCl}, \quad 0.005 \% \mathrm{Fe}_{2}\left(\mathrm{SO}_{4}\right)_{3} \cdot \mathrm{nH}_{2} \mathrm{O}$ (Wako Pure Chemical Industries, Ltd.), $0.005 \% \mathrm{MnSO}_{4} \cdot 5 \mathrm{H}_{2} \mathrm{O}$ ]. A $0.2 \mathrm{ml}$ aliquot of the resultant liquid was mixed into cellobiose asparagine agar $\left(1.0 \%\right.$ cellobiose, $0.1 \%$ L-asparagine, $0.1 \% \mathrm{~K}_{2} \mathrm{HPO}_{4}$, $0.0001 \% \mathrm{FeSO}_{4} .7 \mathrm{H}_{2} \mathrm{O}, 0.0001 \% \mathrm{MnCl}_{2} .4 \mathrm{H}_{2} \mathrm{O}, 0.0001 \%$ $\mathrm{ZnSO}_{4} .7 \mathrm{H}_{2} \mathrm{O}, 1.5 \%$ agar, $\left.\mathrm{pH} 7.0\right)$ and colonies were picked up after incubation for 5 weeks at $27{ }^{\circ} \mathrm{C}$. After culturing on ISP 3 (Nihon Pharmaceutical) and nutrient agar (Difco) for 2-4 weeks at $27{ }^{\circ} \mathrm{C}$, morphology was observed using a scanning electron microscope (SEM; model JSM-5600, JEOL). For SEM inspection, the cultures were fixed with $4 \%$ osmium tetroxide vapour in situ for $16 \mathrm{~h}$ at room temperature and then dried at room temperature. Cultural characteristics were examined on ISP 3, ISP 4 (Difco), ISP 5 (Nihon Pharmaceutical), nutrient agar and HV agar (Hayakawa \& Nonomura, 1987). For the spore motility test, spores of the isolate cultured on nutrient agar for 2 weeks at $27{ }^{\circ} \mathrm{C}$ were suspended and mixed with $0.1 \mathrm{ml}$ sterile tap water or nutrient broth (Difco). After incubation for $1 \mathrm{~h}$ at $27{ }^{\circ} \mathrm{C}$, the spore suspension was observed under a light microscope.

The temperature range, $\mathrm{pH}$ range and the $\mathrm{NaCl}$ tolerance for growth were determined on nutrient agar. Utilization of carbohydrates as sole carbon sources was tested using ISP 9 (Nihon Pharmaceutical) as the basal medium according to the method of Shirling \& Gottlieb (1966). Production of acid was evaluated by using the media of Gordon et al. (1974). ISP 4 (Difco) was used for starch hydrolysis tests, ISP 8 (0.5\% peptone, $0.3 \%$ beef extract, $0.1 \% \mathrm{KNO}_{3}, \mathrm{pH} 7.0$ ) was used for nitrate reduction, glucose-peptone-gelatin medium $(2.0 \%$ glucose, $0.5 \%$ peptone, $20 \%$ gelatin, $\mathrm{pH} 7.0$ ) was used to test for gelatin liquefaction, $10 \%$ skimmed milk (Difco) was used for coagulation and peptonization of milk, ISP 6 (Nihon Pharmaceutical) was used for $\mathrm{H}_{2} \mathrm{~S}$ production and skimmed milk agar (Gordon et al., 1974) was used to test for casein hydrolysis.

Biomass for the molecular systematics and the chemotaxonomic studies was obtained after cultivation in yeast extract-glucose broth $(1.0 \%$ yeast extract, $1.0 \%$ glucose, $\mathrm{pH}$ 7.0) for 3 weeks at $27^{\circ} \mathrm{C}$. After extraction, as described by Collins et al. (1977), isoprenoid quinones were analysed by HPLC with 802 -SC chromatography (JASCO) using a CAPCELL PAK C18 column (Shiseido) (Tamaoka et al., 1983). Isomers of diaminopimelic acid were determined by TLC using whole-cell hydrolysis (Becker et al., 1965). Purified cell walls were prepared according to the method of Kawamoto et al. (1981). Cell-wall amino acids were identified by TLC (Hasegawa et al., 1983) and HPLC (Nozawa et al., 2007). The $\mathrm{N}$-acyl types of muramic acid were determined by the method of Uchida \& Aida (1977). Phospholipids in cells were extracted and identified according to the method of Minnikin et al. (1977). The presence of mycolic acids was examined by TLC following Tomiyasu (1982). Whole-cell sugar composition was analysed according to the methods of Becker et al. (1965). Methyl esters of cellular fatty acids were prepared by direct transmethylation with methanolic hydrochloride using cells grown in nutrient broth (Oxoid) for 10 days at $27{ }^{\circ} \mathrm{C}$ and analysed on a GLC system (HP 6890; Hewlett Packard). Identification and quantification of the fatty acid methyl esters, as well as the numerical analysis of the fatty acid profiles, were performed according to the instructions for the Microbial Identification System (MIDI).

Chromosomal DNA was prepared following the procedure of Saito \& Miura (1963) and the DNA G + C content was determined by HPLC according to Tamaoka \& Komagata (1984). The 16S rRNA gene was amplified using the primers described by Takahashi et al. (2002). Amplifications were performed in a TaKaRa thermal cycler (Takara) with an initial incubation of $1 \mathrm{~min}$ at $95{ }^{\circ} \mathrm{C}$ followed by 30 cycles of $1 \mathrm{~min}$ at $95{ }^{\circ} \mathrm{C}, 1 \mathrm{~min}$ at $50{ }^{\circ} \mathrm{C}$ and $1.5 \mathrm{~min}$ at $72{ }^{\circ} \mathrm{C}$, followed by $2 \mathrm{~min}$ final extension at $72{ }^{\circ} \mathrm{C}$. The PCR products were sequenced on a DNA sequencer (Applied Biosystems 3130 Genetic Analyzer) using a BigDye Terminator v3.1 cycle Sequencing kit (Applied Biosystems), according to the manufacturer's instructions. The CLUSTAL_X program version 1.83 (Thompson et al., 1997) was used for multiple alignments with selected sequences for calculating evolutionary distances (Kimura, 1980). Alignments were manually verified and a phylogenetic tree was constructed based on the neighbour-joining method (Saitou \& Nei, 1987). Data were resampled with 1000 bootstrap replications (Felsenstein, 1985). For the creation of phylogenetic trees by the maximum-likelihood (Felsenstein, 1981) and the maximum-parsimony methods (Kluge \& Farris, 1969), SeaView version 4.2 was used and data were resampled with 100 bootstrap replications. The values for sequence similarities among the most closely related strains were determined using the EzTaxon server (Chun et al., 2007).

Strain K07-0523 ${ }^{\mathrm{T}}$ showed moderate growth and produced long chains of more than 10 spores on ISP 3, ISP 4, ISP 5,

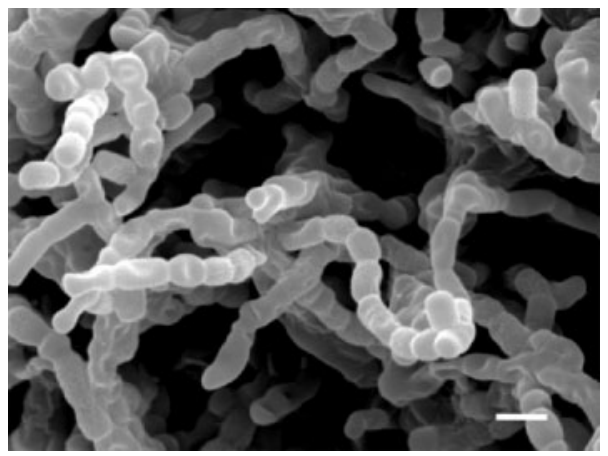

Fig. 1. Scanning electron micrograph of cells of strain $\mathrm{K} 07-0523^{\top}$ grown on ISP 3 for 4 weeks at $27^{\circ} \mathrm{C}$. Bar, $1 \mu \mathrm{m}$. 
nutrient agar and HV agar. Vegetative mycelia were branched, but not fragmented. The surface of the spores was smooth and the spores were $0.8 \times 1.0 \mu \mathrm{m}$ in size (Fig. 1). Spores were non-motile. Sporangia were not observed. The temperature and $\mathrm{pH}$ range for growth were $22-37^{\circ} \mathrm{C}$ and $\mathrm{pH} 7-11$, respectively. Good growth occurred at 26$35{ }^{\circ} \mathrm{C}$ and $\mathrm{pH}$ 7-10. Strain K07-0523 ${ }^{\mathrm{T}}$ did not grow on $3 \%$ $(\mathrm{w} / \mathrm{v}) \mathrm{NaCl}$ medium. Additional physiological characteristics are given in the species description.
The cell-wall peptidoglycan contained D-glutamic acid, glycine, D-alanine, meso-diaminopimelic acid, hydroxydiaminopimelic acid and L-lysine. Galactose, glucose, mannose, ribose and xylose were detected as whole-cell sugars. The $\mathrm{N}$ acyl type of the muramic acid was glycolyl. Phosphatidylethanolamine and five unknown phospholipids were detected but phospholipids containing glucosamine, phosphatidylcholine and phosphatidylglycerol were absent. This polar lipid profile corresponded to phospholipid type II of Lechevalier

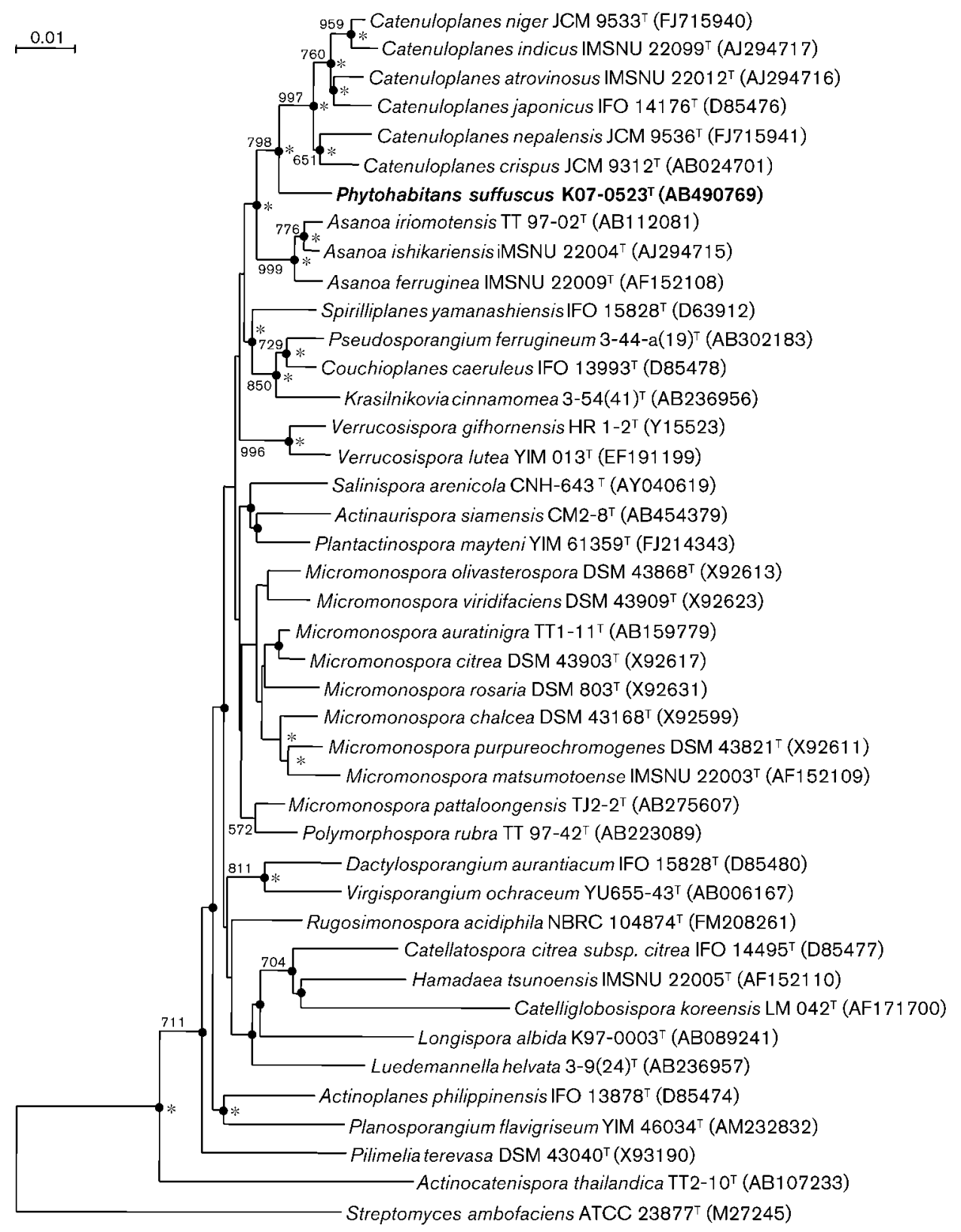

Fig. 2. Neighbour-joining tree based on $16 \mathrm{~S}$ rRNA gene sequences showing relationships between strain $\mathrm{K} 07-0523^{\top}$ and members of family Micromonosporaceae. Only bootstrap values $>50 \%$ (1000 replications) are indicated. The solid circles and asterisks indicate that the corresponding nodes were also recovered in the maximum-likelihood tree and maximum-parsimony trees, respectively. Bar, 0.01 nucleotide substitutions per site. 
Table 1. Morphological features and chemotaxonomic characteristics of the genus Phytohabitans gen. nov. and other genera in the family Micromonosporaceae

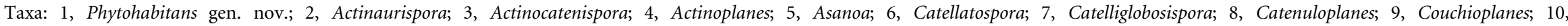

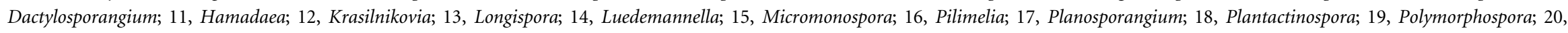

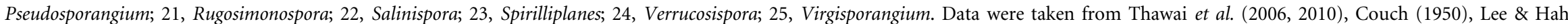

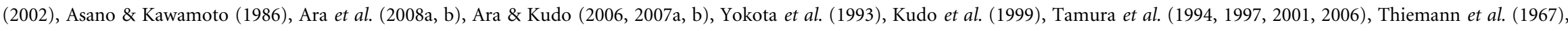

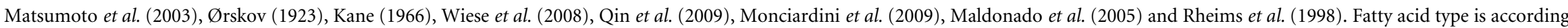

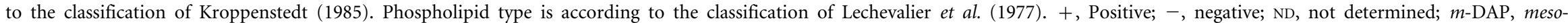
diaminopimelic acid; 3-OH-DAP, 3-hydroxydiaminopileric acid; L-Lys, L-lysine; Ara, arabinose; Gal, galactose; Glc, glucose; Man, mannose; Rha, rhamnose; Rib, ribose; Xyl, xylose.

\begin{tabular}{|c|c|c|c|c|c|c|c|c|c|c|c|c|c|c|c|c|c|c|c|c|c|c|c|c|c|}
\hline Characteristic & 1 & 2 & 3 & 4 & 5 & 6 & 7 & 8 & 9 & 10 & 11 & 12 & 13 & 14 & 15 & 16 & 17 & 18 & 19 & 20 & 21 & 22 & 23 & 24 & 25 \\
\hline Spore motility & - & - & - & + & - & - & - & + & + & + & - & - & - & - & - & + & $+1-$ & - & - & - & - & - & + & - & - \\
\hline Sporangium & - & - & - & + & - & - & - & - & - & + & - & - & - & + & - & + & + & - & - & - & - & - & - & - & + \\
\hline Diamino acid(s) & $\begin{array}{l}m- \\
\text { DAP, } \\
\text { L-Lys }\end{array}$ & $\begin{array}{l}m- \\
\text { DAP }\end{array}$ & $\begin{array}{l}m- \\
\text { DAP }\end{array}$ & $m$-DAP & $\begin{array}{c}m \text {-DAP, } \\
\text { 3-OH- } \\
\text { DAP }\end{array}$ & $\begin{array}{c}m \text {-DAP, } \\
\text { 3-OH- } \\
\text { DAP }\end{array}$ & $\begin{array}{l}m- \\
\text { DAP }\end{array}$ & L-Lys & L-Lys & $m$-DAP & $\begin{array}{c}m- \\
\text { DAP, } \\
3- \\
\text { OH- } \\
\text { DAP }\end{array}$ & $\begin{array}{l}m- \\
\text { DAP }\end{array}$ & $m$-DAP & $\begin{array}{l}m- \\
\text { DAP }\end{array}$ & $\begin{array}{c}m \text {-DAP } \\
\text { and/or } \\
3-\mathrm{OH}- \\
\text { DAP }\end{array}$ & $m$-DAP & $m$-DAP & $\begin{array}{l}m- \\
\text { DAP }\end{array}$ & $m$-DAP & $\begin{array}{c}m- \\
\text { DAP, } \\
3- \\
\text { OH- } \\
\text { DAP }\end{array}$ & $\begin{array}{r}\text { 3-OH- } \\
\text { DAP }\end{array}$ & $\begin{array}{l}m- \\
\text { DAP }\end{array}$ & $\begin{array}{l}m- \\
\text { DAP }\end{array}$ & $\begin{array}{l}m- \\
\text { DAP }\end{array}$ & $\begin{array}{r}3-\mathrm{OH}- \\
\text { DAP }\end{array}$ \\
\hline $\begin{array}{l}\text { Whole-cell } \\
\text { sugars }\end{array}$ & $\begin{array}{l}\text { Gal, Glc, } \\
\text { Man, } \\
\text { Rib, Xyl }\end{array}$ & $\begin{array}{l}\text { Gal, } \\
\text { Man, } \\
\text { Xyl }\end{array}$ & $\begin{array}{c}\text { Ara, } \\
\text { Gal, } \\
\text { Xyl }\end{array}$ & $\begin{array}{l}\text { Ara, } \\
\text { Xyl }\end{array}$ & $\begin{array}{l}\text { Ara, } \\
\text { Gal, Xyl }\end{array}$ & $\begin{array}{c}\text { Ara, } \\
\text { Gal, } \\
\text { Man, } \\
\text { Rha, } \\
\text { Rib, } \\
\text { Xyl or } \\
\text { only } \\
\text { Xyl }\end{array}$ & $\begin{array}{c}\text { Gal, } \\
\text { Glc, } \\
\text { Man, } \\
\text { Rha, } \\
\text { Xyl }\end{array}$ & $\begin{array}{l}\text { Man, } \\
\text { Rib, } \\
\text { Xyl }\end{array}$ & $\begin{array}{r}\text { Ara, } \\
\text { Gal, } \\
\text { Xyl }\end{array}$ & Ara, Xyl & $\begin{array}{c}\text { Ara, } \\
\text { Gal, } \\
\text { Glc, } \\
\text { Man, } \\
\text { Rha, } \\
\text { Rib, } \\
\text { Xyl }\end{array}$ & $\begin{array}{l}\text { Ara, } \\
\text { Gal, } \\
\text { Man, } \\
\text { Rib, } \\
\text { Xyl }\end{array}$ & $\begin{array}{c}\text { Ara, } \\
\text { Gal, } \\
\text { Xyl }\end{array}$ & $\begin{array}{c}\text { Ara, } \\
\text { Gal, } \\
\text { Man, } \\
\text { Rha, } \\
\text { Rib, } \\
\text { Xyl }\end{array}$ & $\begin{array}{c}\text { Ara, } \\
\text { Xyl }\end{array}$ & $\begin{array}{l}\text { Ara, } \\
\text { Xyl }\end{array}$ & $\begin{array}{r}\text { Ara, } \\
\text { Xyl }\end{array}$ & $\begin{array}{c}\text { Ara, Gal, } \\
\text { Xyl }\end{array}$ & Xyl & $\begin{array}{c}\text { Ara, } \\
\text { Gal, } \\
\text { Glc, } \\
\text { Man, } \\
\text { Rib, } \\
\text { Xyl }\end{array}$ & $\begin{array}{c}\text { Ara, } \\
\text { Gal, } \\
\text { Xyl }\end{array}$ & $\begin{array}{c}\text { Ara, } \\
\text { Gal, } \\
\text { Xyl }\end{array}$ & $\begin{array}{l}\text { Gal, } \\
\text { Man, } \\
\text { Xyl }\end{array}$ & $\begin{array}{r}\text { Man, } \\
\text { Xyl }\end{array}$ & $\begin{array}{c}\text { Ara, Gal, } \\
\text { Xyl }\end{array}$ \\
\hline Fatty acid type & $2 \mathrm{~d}$ & $3 b$ & $3 b$ & $2 c$ & $2 \mathrm{~d}$ & $3 b$ & $3 b$ & $2 c$ & $2 c$ & $2 \mathrm{~d}$ & $3 b$ & $2 \mathrm{~d}$ & $2 \mathrm{~d}$ & $2 \mathrm{~d}$ & $3 b$ & $2 b$ & $3 \mathrm{~b}$ & $2 \mathrm{~d}$ & $2 a$ & $2 \mathrm{~d}$ & $2 \mathrm{~d}$ & $3 a$ & $2 \mathrm{~d}$ & $2 b$ & $2 \mathrm{~d}$ \\
\hline $\begin{array}{l}\text { Major } \\
\text { menaquinones }\end{array}$ & $\begin{array}{l}9\left(\mathrm{H}_{6}\right) \\
10\left(\mathrm{H}_{4,6}\right)\end{array}$ & $\begin{array}{l}9\left(\mathrm{H}_{6}\right) \\
10\left(\mathrm{H}_{6}\right)\end{array}$ & $9\left(\mathrm{H}_{4,6}\right)$ & $\begin{array}{l}9\left(\mathrm{H}_{4}\right) \\
10\left(\mathrm{H}_{4}\right)\end{array}$ & $10\left(\mathrm{H}_{6,8}\right)$ & $\begin{array}{c}9\left(\mathrm{H}_{4,6}\right) \\
\text { or } \\
10\left(\mathrm{H}_{4}\right)\end{array}$ & $10\left(\mathrm{H}_{4}\right)$ & $\begin{array}{r}10\left(\mathrm{H}_{4}\right) \\
11\left(\mathrm{H}_{4}\right)\end{array}$ & $9\left(\mathrm{H}_{4}\right)$ & $9\left(\mathrm{H}_{4,6,8}\right)$ & $9\left(\mathrm{H}_{6}\right)$ & $9\left(\mathrm{H}_{4,6,8}\right)$ & $10\left(\mathrm{H}_{4,6}\right) 9$ & $9\left(\mathrm{H}_{4,6}\right)$ & $\begin{array}{l}9\left(\mathrm{H}_{4,6}\right) \\
10\left(\mathrm{H}_{4,6}\right)\end{array}$ & $9\left(\mathrm{H}_{2,4}\right)$ & $10\left(\mathrm{H}_{4}\right)$ & $10\left(\mathrm{H}_{4,6,8}\right)$ & $\begin{array}{l}9\left(\mathrm{H}_{4,6}\right), \\
10\left(\mathrm{H}_{4,6}\right)\end{array}$ & $9\left(\mathrm{H}_{6}\right)$ & $9\left(\mathrm{H}_{8}\right)$ & $9\left(\mathrm{H}_{4}\right)$ & $10\left(\mathrm{H}_{4}\right) \mathrm{S}$ & $9\left(\mathrm{H}_{4}\right)$ & $10\left(\mathrm{H}_{4,6,8}\right)$ \\
\hline $\begin{array}{l}\text { Phospholipid } \\
\text { type }\end{array}$ & II & II & II & II & II & II & II & III & II & II & II & II & II & II & II & II & II & II & II & II & II & II & II & II & II \\
\hline $\begin{array}{c}\text { DNA G +C } \\
\text { content } \\
\text { (mol\%) }\end{array}$ & 73 & 72 & 72 & $72-73$ & $71-72$ & $70-72$ & 70 & $70-73$ & $70-72$ & $72-73$ & 70 & 71 & 70 & 71 & 71 & ND & 71 & 70 & 71 & 73 & $72-73$ & $70-73$ & 69 & 71 & 71 \\
\hline
\end{tabular}


et al. (1977). Mycolic acids were not detected. The predominant menaquinones were MK-9 $\left(\mathrm{H}_{6}\right)(16 \%)$, MK-10 $\left(\mathrm{H}_{4}\right)$ $(21 \%)$ and $\mathrm{MK}-10\left(\mathrm{H}_{6}\right)(33 \%)$ and the minor menaquinones were MK-9 $\left(\mathrm{H}_{4}\right)(6 \%)$, MK-9 $\left(\mathrm{H}_{8}\right)(11 \%)$ and MK-10 $\left(\mathrm{H}_{8}\right)$ $(13 \%)$. The cellular fatty acids representing $>1 \%$ of total fatty acids were anteiso- $\mathrm{C}_{17: 0}(28.6 \%)$, iso- $\mathrm{C}_{17: 0}(19.5 \%)$, iso- $\mathrm{C}_{16: 0}(12.4 \%)$, iso- $\mathrm{C}_{15: 0}(10.2 \%), 9-$ cis- $\mathrm{C}_{18: 1}(5.0 \%), 2-$ $\mathrm{OH}-\mathrm{C}_{16: 1}(4.9 \%), \mathrm{C}_{18: 0}(4.5 \%), 9$-cis- $\mathrm{C}_{17: 1}(2.6 \%)$, anteiso$\mathrm{C}_{15: 0}(2.2 \%), 10$-methyl- $\mathrm{C}_{16: 0}(2.2 \%)$, anteiso- $\mathrm{C}_{17: 1}(1.6 \%)$, $\mathrm{C}_{17: 0}(1.5 \%), \mathrm{C}_{16: 0}(1.3 \%), 9$-cis- $\mathrm{C}_{16: 1}(1.3 \%)$ and iso- $\mathrm{C}_{18: 0}$ $(1.2 \%)$. This profile corresponded to fatty acid type $2 \mathrm{~d}$ of Kroppenstedt (1985). The G $+\mathrm{C}$ content of the genomic DNA was $73 \mathrm{~mol} \%$.

The $16 \mathrm{~S}$ rRNA gene sequence of strain K07-0523 ${ }^{\mathrm{T}}$ showed a close relationship with members of family Micromonosporaceae. Similarity values between strain $\mathrm{K} 07-0523^{\mathrm{T}}$ and the type species of all genera belonging to the family Micromonosporaceae were $93.3-97.7 \%$. The species showing the highest similarity values to strain $\mathrm{K} 07-0523^{\mathrm{T}}$ were Micromonospora pattaloongensis (97.7\%), Pseudosporangium ferrugineum (97.7\%), Micromonospora auratinigra (97.6\%) and Catenuloplanes crispus (97.6\%). The phylogenetic analysis based on the 16S rRNA gene sequences also indicated that the new isolate fell within the lineage of the family Micromonosporaceae and formed a cluster within the genera Catenuloplanes and Asanoa (Fig. 2) (see Supplementary Figures S1 and S2 in IJSEM Online). Signature nucleotides of the $16 \mathrm{~S}$ rRNA gene sequence of strain $\mathrm{K} 07-0523^{\mathrm{T}}$ were shared in all positions with genera of the family Micromonosporaceae (Zhi et al., 2009).

Strain K07-0523 ${ }^{\mathrm{T}}$ could be classified as a member of the family Micromonosporaceae on the basis of both the phylogenetic analysis and the fact that the $\mathrm{N}$-acyl type of muramic acid was glycolyl. However, strain K07-0523 ${ }^{\mathrm{T}}$ could be distinguished from all genera of the family Micromonosporaceae by the unique characteristic that the cell-wall peptidoglycan contained both meso-diaminopimelic acid and L-lysine as the diamino acids (Table 1). Furthermore, strain K07-0523 $3^{\mathrm{T}}$ was clearly different from members of the genera Micromonospora, Pseudosporangium and Catenuloplanes, with which it showed high $16 \mathrm{~S}$ rRNA gene sequence similarity values, on the basis of their morphology, as these genera form only single spores, pseudosporangia or motile spores, respectively. The genera Catenuloplanes and Asanoa, which clustered with strain K07$0523^{\mathrm{T}}$ on the phylogenetic tree, could be distinguished from strain $\mathrm{K} 07-0523^{\mathrm{T}}$ by the major menaquinones, the characteristic whole-cell sugars, the fatty acid profile and the phospholipid profile (Table 1). On the basis of the above results, it is proposed that strain $\mathrm{K} 07-0523^{\mathrm{T}}$ represents a novel genus and species in the family Micromonosporaceae, namely Phytohabitans suffuscus gen. nov., sp. nov.

\section{Description of Phytohabitans gen. nov.}

Phytohabitans (Phy.to.ha'bi.tans. Gr. n. phyton plant; L. part. adj. habitans inhabiting; N. L. part. adj. used as a masc. n. Phytohabitans plant-inhabiting, isolated from plants).

Aerobic, Gram-positive and mesophilic actinomycetes. Vegetative mycelia are branched and not fragmented. Spores are non-motile. Cell wall contains D-glutamic acid, glycine, D-alanine, meso-diaminopimelic acid and L-lysine. Whole-cell sugars are galactose, glucose, mannose, ribose and xylose. The acyl type of the peptidoglycan is glycolyl. Phosphatidylethanolamine is detected, corresponding to phospholipid type II. Mycolic acids are not detected. Predominant menaquinones are MK- $9\left(\mathrm{H}_{6}\right), \mathrm{MK}-10\left(\mathrm{H}_{4}\right)$ and $\mathrm{MK}-10\left(\mathrm{H}_{6}\right)$. The $\mathrm{G}+\mathrm{C}$ content of the genomic DNA is $73 \mathrm{~mol} \%$. The type species is Phytohabitans suffuscus.

\section{Description of Phytohabitans suffuscus sp. nov.}

Phytohabitans suffuscus (suff.us'cus. L. masc. adj. suffuscus brownish, named after the brownish colour of the vegetative mycelium).

Morphological, chemotaxonomic and cultural characteristics are as given in the genus description above. Good growth occurs at $26-35{ }^{\circ} \mathrm{C}$ and at $\mathrm{pH} 7-10$. No growth on $3 \%(\mathrm{w} / \mathrm{v}) \mathrm{NaCl}$. Exhibits moderate growth and forms long chains, of more than 10 spores, on ISP 3, ISP 4, ISP 5, nutrient agar and $\mathrm{HV}$ agar. The surface of the spores is smooth and spore size is $0.8 \times 1.0 \mu \mathrm{m}$. The vegetative mycelia are pale orange to pale brown in colour. Soluble pigment is not produced. Major fatty acids are anteiso$\mathrm{C}_{17: 0}$, iso- $\mathrm{C}_{17: 0}$, iso- $\mathrm{C}_{16: 0}$, iso- $\mathrm{C}_{15: 0}$. Degrades casein and weakly hydrolyses gelatin. Does not hydrolyse starch. Peptonizes and coagulates milk. Acid is produced from fructose, arabinose, mannitol, rhamnose, galactose and glucose. No acid is produced from raffinose. Nitrate is not reduced to nitrite. $\mathrm{H}_{2} \mathrm{~S}$ is not produced. Utilizes D-glucose, D-mannitol, sucrose, D-fructose, D-galactose, L-rhamnose, D-xylose, D-mannose, raffinose, L-arabinose. Does not utilize maltose, dulcitol, D-sorbitol, methyl $\alpha$-D-glucopyranoside, $\beta$-lactose, trehalose, adonitol, melibiose, myoinositol or meso-erythritol.

The type strain, K07-0523 ${ }^{\mathrm{T}} \quad\left(=\mathrm{DSM} \quad 45306^{\mathrm{T}}=\mathrm{NBRC}\right.$ $\left.105367^{\mathrm{T}}\right)$, was isolated from the roots of an orchid.

\section{Acknowledgements}

This work was financially supported in part by a research grant (20082011) of the Institute for Fermentation, Osaka (IFO), Japan. We thank Professor Jean P. Euzéby (Society for Systematic and Veterinary Bacteriology) for his help with the nomenclature and Dr Yuriko Nozawa (Medicinal Chemistry Laboratory, Taisho Pharmaceutical Co., Ltd) for her help with the analysis of amino acids.

\section{References}

Ara, I. \& Kudo, T. (2006). Three novel species of the genus Catellatospora, Catellatospora chokoriensis sp. nov., Catellatospora coxensis sp. nov. and Catellatospora bangladeshensis sp. nov. and transfer of Catellatospora citrea subsp. methionotrophica Asano and 
Kawamoto 1988 to Catellatospora methionotrophica sp. nov., comb. nov. Int J Syst Evol Microbiol 56, 393-400.

Ara, I. \& Kudo, T. (2007a). Luedemannella gen. nov., a new genus of the family Micromonosporaceae and description of Luedemannella helvata sp. nov. and Luedemannella flava sp. nov. J Gen Appl Microbiol 53, 39-51.

Ara, I. \& Kudo, T. (2007b). Krasilnikovia gen. nov., a new genus of the family Micromonosporaceae and description of Krasilnikovia cinnamonea sp. nov. Actinomycetologica 21, 1-10.

Ara, I., Matsumoto, A., Bakir, M. A., Kudo, T., Ōmura, S. \& Takahashi, Y. (2008a). Pseudosporangium ferrugineum gen. nov., sp. nov., a new member of the family Micromonosporaceae. Int J Syst Evol Microbiol 58, 1644-1652.

Ara, I., Bakir, M. A. \& Kudo, T. (2008b). Transfer of Catellatospora koreensis Lee et al. 2000 as Catelliglobosispora koreensis gen. nov., comb. nov. and Catellatospora tsunoense Asano et al. 1989 as Hamadaea tsunoensis gen. nov., comb. nov., and emended description of the genus Catellatospora Asano and Kawamoto 1986 emend. Lee and Hah 2002. Int J Syst Evol Microbiol 58, 1950-1960.

Asano, K. \& Kawamoto, I. (1986). Catellatospora, a new genus of the Actinomycetales. Int J Syst Bacteriol 36, 512-517.

Becker, B., Lechevalier, M. P. \& Lechevalier, H. A. (1965). Chemical composition of cell-wall preparation from strains of various formgenera of aerobic actinomycetes. Appl Microbiol 13, 236-243.

Chun, J., Lee, J.-H., Jung, Y., Kim, M., Kim, S., Kim, B. K. \& Lim, Y. W. (2007). EzTaxon: a web-based tool for the identification of prokaryotes based on $16 \mathrm{~S}$ ribosomal RNA gene sequences. Int J Syst Evol Microbiol 57, 2259-2261.

Collins, M. D., Pirouz, T., Goodfellow, M. \& Minnikin, D. E. (1977). Distribution of menaquinones in actinomycetes and corynebacteria. J Gen Microbiol 100, 221-230.

Couch, J. N. (1950). Actinoplanes a new genus of the Actinomycetales. J Elisha Mitchell Sci Soc 66, 87-92.

Felsenstein, J. (1981). Evolutionary trees from DNA sequences: a maximum likelihood approach. J Mol Evol 17, 368-376.

Felsenstein, J. (1985). Confidence limits on phylogenies: an approach using the bootstrap. Evolution 39, 783-791.

Gordon, R. E., Barnett, D. A., Handerhan, J. E. \& Pang, C. H.-N. (1974). Nocardia coeliaca, Nocardia autotrophica, and the nocardin strain. Int J Syst Bacteriol 24, 54-63.

Hasegawa, T., Takizawa, M. \& Tanida, S. (1983). A rapid analysis for chemical grouping of aerobic actinomycetes. J Gen Appl Microbiol 29, 319-322.

Hayakawa, M. \& Nonomura, H. (1987). Humic acid-vitamin agar, a new medium for selective isolation of soil actinomycetes. $J$ Ferment Technol 65, 501-509.

Kane, W. D. (1966). A new genus of Actinoplanaceae, Pilimelia, with a description of two species, Pilimelia terevasa and Pilimelia anulata. J Elisha Mitchell Sci Soc 82, 220-230.

Kawamoto, I., Oka, T. \& Nara, T. (1981). Cell wall composition of Micromonospora olivasterospora, Micromonospora sagamiensis, and related organisms. J Bacteriol 146, 527-534.

Kimura, M. (1980). A simple method for estimating evolutionary rates of base substitutions through comparative studies of nucleotide sequences. J Mol Evol 16, 111-120.

Kluge, A. G. \& Farris, J. S. (1969). Quantitative phyletics and the evolution of anurans. Syst Zool 18, 1-32.

Koch, C., Kroppenstedt, R. M., Rainey, F. A. \& Stackebrandt, E. (1996). 16S ribosomal DNA analysis of the genera Micromonospora, Actinoplanes, Catellatospora, Catenuloplanes, Couchioplanes,
Dactylosporangium, and Pilimelia and emendation of the family Micromonosporaceae. Int J Syst Bacteriol 46, 765-768.

Krasil'nikov, N. A. (1938). Ray Fungi and Related Organisms Actinomycetales. Moscow: Akademii Nauk USSR.

Kroppenstedt, R. M. (1985). Fatty acid and menaquinone analysis of actinomycetes and related organisms. In Chemical Methods in Bacterial Systematics (Society for Applied Bacteriology Technical Series vol. 20), pp. 173-199. Edited by M. Goodfellow \& D. E. Minnikin. New York: Academic Press.

Kudo, T., Nakajima, Y. \& Suzuki, K. (1999). Catenuloplanes crispus (Petrolini et al. 1993) comb. nov.: incorporation of the genus Planopolyspora Petrolini 1993 into the genus Catenuloplanes Yokota et al. 1993 with an amended description of the genus Catenuloplanes. Int J Syst Bacteriol 49, 1853-1860.

Lechevalier, H. A. \& Lechevalier, M. P. (1967). Biology of actinomycetes. Annu Rev Microbiol 21, 71-100.

Lechevalier, M. P., De Bièvre, C. \& Lechevalier, H. A. (1977). Chemotaxonomy of aerobic actinomycetes: phospholipid composition. Biochem Syst Ecol 5, 249-260.

Lee, S. D. \& Hah, Y. C. (2002). Proposal to transfer Catellatospora ferruginea and 'Catellatospora ishikariense' to Asanoa gen. nov. as Asanoa ferruginea comb. nov. and Asanoa ishikariensis sp. nov., with emended description of the genus Catellatospora. Int J Syst Evol Microbiol 52, 967-972.

Maldonado, L. A., Fenical, W., Jensen, P. R., Kauffman, C. A., Mincer, T. J., Ward, A. C., Bull, A. T. \& Goodfellow, M. (2005). Salinispora arenicola gen. nov., sp. nov. and Salinispora tropica sp. nov., obligate marine actinomycetes belonging to the family Micromonosporaceae. Int J Syst Evol Microbiol 55, 1759-1766.

Matsumoto, A., Takahashi, Y., Mochizuki, M., Seino, A., Iwai, Y. \& Ōmura, S. (1998). Characterization of actinomycetes isolated from fallen leaves. Actinomycetologica 12, 46-48.

Matsumoto, A., Takahashi, Y., Shinose, M., Seino, A., Iwai, Y. \& Ōmura, S. (2003). Longispora albida gen. nov., sp. nov., a novel genus of the family Micromonosporaceae. Int J Syst Evol Microbiol 53, 15531559.

Minnikin, D. E., Patel, P. V., Alshamaony, L. \& Goodfellow, M. (1977). Polar lipid composition in the classification of Nocardia and related bacteria. Int J Syst Bacteriol 27, 104-117.

Monciardini, P., Cavaletti, L., Ranghetti, A., Schumann, P., Rohde, M., Bamonte, R., Sosio, M., Mezzelani, A. \& Donadio, S. (2009). Novel members of the family Micromonosporaceae, Rugosimonospora acidiphila gen. nov., sp. nov. and Rugosimonospora africana sp. nov. Int J Syst Evol Microbiol 59, 2752-2758.

Nozawa, Y., Sasaki, N., Arai, K., Kawasaki, Y. \& Harada, K. (2007). Reliable and sensitive analysis of amino acids in the peptidoglycan of actinomycetes using the advanced Marfey's method. J Microbiol Methods 70, 306-311.

Okazaki, K., Takahashi, K., Kuzuka, M. \& Enokita, R. (1995). Studies on actinomycetes isolated from plant leaves. Ann Rep Snakyo Res Lab 47, 97-106.

Ørskov, J. (1923). Investigations into the Morphology of the Ray Fungi. Copenhagen: Levin and Munksgaard.

Qin, S., Li, J., Zhang, Y.-Q., Zhu, W.-Y., Zhao, G.-Z., Xu, L.-H. \& Li, W.-J. (2009). Plantactinospora mayteni gen. nov., sp. nov., a member of the family Micromonosporaceae. Int J Syst Evol Microbiol 59, 25272533.

Rheims, H., Schumann, P., Rohde, M. \& Stackebrandt, E. (1998). Verrucosispora gifhornensis gen. nov., sp. nov., a new member of the actinobacterial family Micromonosporaceae. Int J Syst Bacteriol 48, 1119-1127. 
Saito, H. \& Miura, K. (1963). Preparation of transforming deoxyribonucleic acid by phenol treatment. Biochim Biophys Acta 72, 619-629.

Saitou, N. \& Nei, M. (1987). The neighbor-joining method: a new method for reconstructing phylogenetic trees. Mol Biol Evol 4, 406425.

Shirling, E. B. \& Gottlieb, D. (1966). Methods for characterization of Streptomyces species. Int J Syst Bacteriol 16, 313-340.

Stackebrandt, E., Rainey, F. A. \& Ward-Rainey, N. L. (1997). Proposal for a new hierarchic classification system, Actinobacteria classis nov. Int J Syst Bacteriol 47, 479-491.

Takahashi, Y., Matsumoto, A., Seino, A., Ueno, J., Iwai, Y. \& Mura, S. (2002). Streptomyces avermectinius sp. nov., an avermectin-producing strain. Int J Syst Evol Microbiol 52, 2163-2168.

Tamaoka, J. \& Komagata, K. (1984). Determination of DNA base composition by reversed-phase high-performance liquid chromatography. FEMS Microbiol Lett 25, 125-128.

Tamaoka, J., Katayama-Fujimura, Y. \& Kuraishi, H. (1983). Analysis of bacterial menaquinone mixtures by high performance liquid chromatography. J Appl Bacteriol 54, 31-36.

Tamura, T., Nakagaito, Y., Nishii, T., Hasegawa, T., Stackebrandt, E. \& Yokota, A. (1994). A new genus of the order Actinomycetales, Couchioplanes gen. nov., with descriptions of Couchioplanes caeruleus (Horan and Brodsky 1986) comb. nov. and Couchioplanes caeruleus subsp. azureus subsp. nov. Int J Syst Bacteriol 44, 193-203.

Tamura, T., Hayakawa, M. \& Hatano, K. (1997). A new genus of the order Actinomycetales, Spirilliplanes gen. nov., with description of Spirilliplanes yamanashiensis sp. nov. Int J Syst Bacteriol 47, 97-102.

Tamura, T., Hayakawa, M. \& Hatano, K. (2001). A new genus of the order Actinomycetales, Virgosporangium gen. nov., with descriptions of Virgosporangium ochraceum sp. nov. and Virgosporangium aurantiacum sp. nov. Int J Syst Evol Microbiol 51, 1809-1816.

Tamura, T., Hatano, K. \& Suzuki, K. (2006). A new genus of the family Micromonosporaceae, Polymorphospora gen. nov., with description of
Polymorphospora rubra sp. nov. Int J Syst Evol Microbiol 56, 1959 1964.

Thawai, C., Tanasupawat, S., Itoh, T. \& Kudo, T. (2006). Actinocatenispora thailandica gen. nov., sp. nov., a new member of the family Micromonosporaceae. Int J Syst Evol Microbiol 56, 17891794.

Thawai, C., Tanasupawat, S., Suwanborirux, K. \& Kudo, T. (2010). Actinaurispora siamensis gen. nov., sp. nov., a new member of the family Micromonosporaceae. Int J Syst Evol Microbiol 60, 1660-1666.

Thiemann, J. E., Pagani, H. \& Beretta, G. (1967). A new genus of the Actinoplanaceae: Dactylosporangium, gen. nov. Arch Mikrobiol 58, 42 52.

Thompson, J. D., Gibson, T. J., Plewniak, F., Jeanmougin, F. \& Higgins, D. G. (1997). The CLUSTAL_X windows interface: flexible strategies for multiple sequence alignment aided by quality analysis tools. Nucleic Acids Res 25, 4876-4882.

Tomiyasu, I. (1982). Mycolic acid composition and thermally adaptative changes in Nocardia asteroides. J Bacteriol 151, 828-837.

Uchida, K. \& Aida, K. (1977). Acyl type of bacterial cell wall: its simple identification by a colorimetric method. J Gen Appl Microbiol 23, 249-260.

Wiese, J., Jiang, Y., Tang, S., Thiel, V., Schmaljohann, R., Xu, L., Jiang, C. \& Imhoff, J. F. (2008). A new member of the family Micromonosporaceae, Planosporangium flavigriseum gen. nov., sp. nov. Int J Syst Evol Microbiol 58, 1324-1331.

Yokota, A., Tamura, T., Hasegawa, T. \& Huang, L. H. (1993). Catenuloplanes japonicus gen. nov., sp. nov., nom. rev., a new genus of the order Actinomycetales. Int J Syst Bacteriol 43, 805-812.

Zhi, X.-Y., Li, W.-J. \& Stackebrandt, E. (2009). An update of the structure and 16S rRNA gene sequence-based definition of higher ranks of the class Actinobacteria, with the proposal of two new suborders and four new families and emended descriptions of the existing higher taxa. Int J Syst Evol Microbiol 59, 589-608. 